\title{
Portfolio Management Services in India: Returns and Incentives
}

\author{
Vaibhav Aggarwal,", Chintan Vadgama ${ }^{2}$ \\ ${ }^{1}$ O.P. Jindal Global University, Haryana, India \\ ${ }^{2}$ Emirates Institute of Banking \& Financial Studies, United Arab Emirates
}

Received November 23, 2021; Revised December 18, 2021; Accepted February 8, 2022

\section{Cite This Paper in the following Citation Styles}

(a): [1] Vaibhav Aggarwal, Chintan Vadgama, "Portfolio Management Services in India: Returns and Incentives," Universal Journal of Accounting and Finance, Vol. 10, No. 2, pp. 476 - 482, 2022. DOI: 10.13189/ujaf.2022.100212.

(b): Vaibhav Aggarwal, Chintan Vadgama (2022). Portfolio Management Services in India: Returns and Incentives. Universal Journal of Accounting and Finance, 10(2), 476 - 482. DOI: 10.13189/ujaf.2022.100212.

Copyright $\bigcirc 2022$ by authors, all rights reserved. Authors agree that this article remains permanently open access under the terms of the Creative Commons Attribution License 4.0 International License

\begin{abstract}
On the back of booming equity markets and falling interest rates, Indian high net worth investors have flocked to Portfolio Management Services (PMS) funds in India with substantial assets under management of INR $18,07,939$ crores. However, there is scant academic literature on the performance of PMS funds in India which charge high fees compared to passive index funds. The purpose of this study is twofold. First, describe the performance of PMS funds in India as compared to their respective benchmark. Secondly, review the incentives fees structure of PMS funds and recommend regulatory changes needed to address the shortcomings. The principal results indicate that majority of PMS funds have failed to outperform the benchmark in the short-term and medium-term periods. In the long-term period, however, largely PMS funds have beaten the benchmark returns. The implications of this study are two-fold in the Indian market context. First, high net worth individuals in India must invest via PMS funds only if their investment time horizon is at least ten years. For the short to medium-term, it will be better to invest in index funds due to their meager expense ratio and returns, which are like the benchmark indices. Second, Indian policymakers must increase the minimum hurdle rate based on which the variable performance fee is charged to ensure portfolio managers are rewarded if they generate abnormal risk-adjusted returns. This study contributes to academic literature by focusing on the performance and incentives of PMS funds market in India, which is largely unexplored till now.
\end{abstract}

Keywords PMS, Mutual Fund, SEBI, India, Risk, Return, Incentive Fees

\section{JEL Classification: G1, G2, G4}

\section{Introduction}

Central banks across the world after the global financial crisis of 2008 have adopted a soft interest rate regime, which has made investments in fixed income securities less attractive for investors. A large number of investors have started investing in equity markets, hoping for better returns. Due to limited market knowledge, most of the small retail investors have gone for the indirect route of investments via mutual funds (MF), which charge management fees. High net worth individuals (HNIs), on the other hand, have also chosen Hedge Funds in developed countries and Portfolio Management Services (PMS) in developing countries on the promise of personalized services and superior portfolio management skills. Hedge funds can attract HNIs despite additional performance fees since they provide exotic risk component apart from the traditional risk component [1]. The fee structure in hedge funds is popularly called " 2 and 20 " implying fixed fees of $2 \%$ and $20 \%$ performance returns above the hurdle rate [13].

The performance of MFs has been an area of significant academic interest over the past decade in developed and emerging countries like India. Using the TM and HM regressions model to analyze the market timing ability of $30 \mathrm{MFs}$, found that only $13(43 \%)$ exhibited superior timing skills [36]. In a study of 31 tax saving mutual 
schemes from December 1995 to January 2004, it was found the majority of the fund managers did not provide abnormal returns compared to the benchmark [34]. Similar results were found in a study on 133 open-ended mutual funds, and the average aggregate performance was significantly negative compared to the S\&P CNX 500 benchmark [32]. On the contrary, most of the equity growth funds outperformed in the benchmark BSE100 index, which is evidence of satisfactory risk-adjusted returns [8].

There is scant literature covering the risk-adjusted returns of PMS funds in the Indian context. The country has seen a rising number of HNIs interested in making high returns and an appetite to invest in the Indian stock markets. They have turned to Portfolio Management Services for their expert services. The Assets under management (AUM) of PMS industry has seen a tremendous rise from INR 4,72,520 crores in February 2012 to INR 18,07,939 crores in April 2019 [29,30]. PMS funds can be either discretionary or non-discretionary. Discretionary PMS allows the fund manager to make investment decisions via a power of attorney. On the other hand, in non-discretionary PMS, the portfolio manager needs to confirm each investment decision with the client.

PMS funds differ from traditional mutual funds in several ways. Firstly, different PMS fund managers have the freedom to choose management fees, performance fees, entry, and exit loads. In contrast, in the case of mutual funds, there is a maximum cap set by the Securities and Exchange Board of India (SEBI). Secondly, PMS is suitable only for HNIs with the minimum entry ticket size of at least INR 50 lacs as compared to paltry INR 500 for mutual funds.

The contribution of this study is multifold. First, to the best of the author's knowledge, this is the first research analyzing the performance of various PMS funds in India. Second, this study also focusses on the fee structure of PMS funds and whether it is justified. The high fees to equity portfolio managers are rationale only if more value is provided in terms of risk-adjusted returns [18]. Third, the focus is on HNIs investing in PMS funds as compared to earlier studies that have focused on MFs performance, which also cater to retail investors.

The results indicate that PMS funds collective performance has been ordinary in both the short term and medium term. But, with a period exceeding ten years, all the PMS funds in this study have managed to outperform the benchmark. The findings of this study are beneficial for HNIs who should only invest via PMS funds if they are looking for a long-term horizon of close to 10 years or more. In the case of a shorter time horizon, it is advisable to invest in passive mutual funds or ETF, which have meager fees expenses and mimic the performance of benchmark indices. Further, it is also found that the hurdle rate set by most PMS funds is very conservative of $10 \%$ or less, which is a basis of charging variable performance fees. The regulator should increase the minimum hurdle rate to ensure that portfolio managers only get variable fees on generating an abnormal alpha. Further, clawback provisions should be made so that portfolio managers are also penalized for poor asset allocation at times of significant equity market drawdowns.

The remainder of this paper is structured as follows. The literature review is discussed in Section 2. Section 3 depicts the data and methodology. The analysis and interpretation are discussed in section 4. Conclusion and implications are mentioned in Section 5.

\section{Review of Literature}

The fees charged by index funds are much lower as compared to active funds, which have sparked significant academic literature over the past few decades on the analysis of risk-adjusted returns provided by both active and passive mutual funds. It is critical for investors to evaluate the risks alongside the expected returns involved before taking an investment decision [25]. Investors exhibit heterogeneity on the rationale on selecting a particular mode to invest money [31].

The theoretical underpinnings why active management will not add value to investors is three-fold. First, the average active fund underperforms after adjusting for fees; secondly, even the performance of best performing funds remains consistent over a long horizon, thirdly few fund managers have superior active management skills, which are offset by fees charged [11].

The majority of the early literature focused on developed economies found that active funds have underperformed after accounting for fees as compared to underlying benchmark as well as passive index funds. In a pioneering study, it was found that active mutual funds on an average did not predict security prices efficiently and underperform after fees [22]. This was also found in a study that active management resulted in lower investor returns, and very fewer funds are generating risk-adjusted excess returns to justify the costs charged [15]. There is no evidence of superior performance by active fund managers due to either skill or information [7]. In a study using a stochastic dominance test, it was found that abnormal performance of the top active funds vanished when accounting for residual risk, and a risk-averse investor should not select any random active fund over an index fund [10]. Further segregated active funds and found that funds sold via brokers underperformed due to weaker incentives to create excess returns, while directly marketed segment did not underperform the benchmark index [20]. An inverse relationship between returns generated by active fund management was observed with an increase in the size signaling diseconomies of scale [28].

The superior performance of index funds has resulted in a dramatic shift in investor preferences with net purchases 
of around $\$ 1$ trillion in index funds, while about $\$ 600$ billion net outflows is seen from active mutual funds after 2008 [5]. The higher risk-adjusted returns of passive Exchange Traded Funds (ETF) after the global financial crisis of 2008 make for an attractive investment avenue [24,35].

The recent strand of literature has focused on emerging economies that are attracting increased investor interest in the stock markets on the back of higher economic growth, and the empirical findings have thrown mixed results. In a study on China, Russia, India, and Brazil, no significant alpha generation over benchmark indices was found by domestic fund managers to justify higher management fees for active management [16]. The top-performing active mutual fund managers in China are shifting to hedge funds due to better compensation, causing a decline in performance persistence at an aggregate level in the active fund industry [9]. On the other hand, active funds were found to generate excess post-tax returns of $2.75 \%$ as compared to ETFs only, which are considered a suitable proxy for passive index funds [23]. The active management is generating excess returns of $1.8 \%$ over passive management in emerging economies where stock market efficiency is lower compared to developed economies [14].

Some researchers have focused on the dark sides of a massive shift to passive investment funds. It was also studied that BlackRock, Vanguard and State Street together comprise of the largest shareholding in $88 \%$ of the S\&P companies and exert hidden power by private engagements with the management of these companies [17]. Higher passive investment ownership affected corporate governance adversely because of higher CEO power, fewer new independent directors, and poor mergers \& acquisition decisions [33].

Research is rapidly growing to investigate the risk-adjusted performance of hedge funds due to the continuous trend of increasing AUM. Many studies found that the performance of hedge funds using a dollar-weighted performance gap and factor model of risk, which was found lower than the benchmark S\&P 500 index and marginally higher than the risk-free rate [12]. Another set of studies found the absence of multi duration persistence of returns in hedge funds $[2,6]$. In novel hedge fund manager compensation "first loss scheme" will give improve investor utilities and reduce fund risk as compared to the traditional compensation structure [21]. In the "first loss scheme" any fund loss will be first compensated by own investment by fund manager, increasing the skin in the game. Clawback provisions where the performance fees payout is dependent on exceeding the earlier asset price increase symmetry between investor and hedge fund manager payout [19].

The academic literature focusing on the active versus passive debate in an emerging country like India is growing with significant attention to the performance of active mutual funds. But the performance of PMS funds providing active management services to HNIs remains largely one unexplored. To the best of authors' knowledge, there is only one academic study which examined the risk return performance of a particular PMS fund - Reliance Nippon Asset Management Limited [26]. In this study, this research gap is aimed to examine whether the fees charged by PMS funds are providing value addition to their clients.

\section{Data and Methodology}

The major hypothesis being tested in the study is whether the PMS funds perform better in comparison to the underlying benchmark indices over different time periods. Further, a descriptive analysis has also been done to evaluate whether the hurdle rate chosen by the PMS funds for computing outperformance for earning variable pay is appropriate or not.

\subsection{Consolidated Historical Performance: PMS Funds}

The data regarding historical return of PMS funds, has been obtained from the website www.pmsbazaar.com which is a leading aggregator of various PMS fund performance in India. The rationale for choosing a third-party aggregator, is because the data made available on the SEBI website is not sufficient to analyze the performance of PMS funds industry.

Table 1 depicts the historical return performance of PMS funds as compared to underlying benchmark indices for the year ending $31^{\text {st }}$ December 2019 for different periods of one year, three years, five years, and ten years. Only seventeen funds that have completed at least ten years are included in this analysis. It is important to note that the underlying benchmark indices differ from one fund to another depending on the investment objective and mandate i.e., a PMS fund which invests money in small cap stocks can have NIFTY SMALLCAP 100 as a benchmark, while a PMS fund which parks money in mid-cap stocks can have NIFTY MIDCAP 100. Here, the actual details of the benchmark indices for all the 17 PMS funds are not mentioned, because of unavailability of data.

\subsection{Best and Worst Performing: PMS Funds}

Table 2 depicts the pre-fees historical performance of individual PMS funds for the year ending $31^{\text {st }}$ December 2019 for one, two, three, and five years. Due to a lack of availability of data for ten years at PMS fund specific level, it has not been included in this analysis. The source of data is the PMS Bazaar report "PMS \& AIF" 2020. 
Table 1. Aggregate Performance of PMS Funds

\begin{tabular}{|c|c|c|c|c|}
\hline Period & Total Numbers & $\begin{array}{c}\text { Outperformed the } \\
\text { Benchmark }\end{array}$ & $\begin{array}{c}\text { Underperformed the } \\
\text { Benchmark }\end{array}$ & $\begin{array}{c}\text { In-line with Benchmark } \\
( \pm 1 \%)\end{array}$ \\
\hline 1 Year & 17 & 9 & 7 & 1 \\
\hline 3 Years & 17 & 5 & 3 & 7 \\
\hline 5 Years & 17 & 10 & 0 & 0 \\
\hline 10 Years & 17 & 17 & 0 & 7 \\
\hline
\end{tabular}

Source: PMS Bazaar report "PMS \& AIF” 2020

Table 2. Best performing strategy wise PMS funds in the last five years (all performance as on $29^{\text {th }}$ February 2020. Returns are in $\%$ CAGR and reported pre fees)

\begin{tabular}{|c|c|c|c|c|c|c|}
\hline PMS Name & Category & Strategy & 1 Year & 2 Year & 3 Year & 5 Year \\
\hline Ambit Capital & Mid Cap & Ambit Capital Good \& Clean India Fund & $16.90 \%$ & $11.40 \%$ & $12.70 \%$ & $12.00 \%$ \\
\hline Narnolia & Multi Cap & Narnolia India 3t & $7.00 \%$ & $-1.70 \%$ & $6.70 \%$ & $11.80 \%$ \\
\hline $\begin{array}{l}\text { Ask Investment } \\
\text { Managers }\end{array}$ & Multi Cap & Ask - IEP & $16.80 \%$ & $10.10 \%$ & $13.40 \%$ & $11.10 \%$ \\
\hline $\begin{array}{l}\text { Alchemy Capital } \\
\text { Management }\end{array}$ & Multi Cap & Alchemy High Growth Select Stock & $7.50 \%$ & $3.10 \%$ & $10.10 \%$ & $10.70 \%$ \\
\hline $\begin{array}{l}\text { Ask Investment } \\
\text { Managers }\end{array}$ & Multi Cap & Ask. India Select & $17.90 \%$ & $6.90 \%$ & $9.90 \%$ & $9.90 \%$ \\
\hline Alfaccurate Advisors & Multi Cap & Alfaccurate Advisors IOP & $9.37 \%$ & $3.12 \%$ & $8.32 \%$ & $9.82 \%$ \\
\hline Nippon India & Multi Cap & Nippon India - High Conviction & $20.20 \%$ & $6.70 \%$ & $9.50 \%$ & $9.40 \%$ \\
\hline Accuracap & Large Cap & Accuracap - Alpha10 & $13.00 \%$ & $7.90 \%$ & $11.90 \%$ & $9.20 \%$ \\
\hline Alfaccurace Advisors & Multi Cap & Alfaccurate - AAA Focus Plan & $13.91 \%$ & $1.26 \%$ & $9.96 \%$ & $9.06 \%$ \\
\hline Centrum PMS & Mid Cap & Centrum Multibagger (Deep Value I) & $23.80 \%$ & $1.30 \%$ & $8.90 \%$ & $8.70 \%$ \\
\hline $\begin{array}{l}\text { Alchemy Capital } \\
\text { Management }\end{array}$ & Large Cap & Alchemy - Leaders & $11.50 \%$ & $3.40 \%$ & $10.90 \%$ & $8.60 \%$ \\
\hline $\begin{array}{l}\text { Alchemy Capital } \\
\text { Management }\end{array}$ & Multi Cap & Alchemy - High Growth & $2.10 \%$ & $3.50 \%$ & $5.10 \%$ & $7.50 \%$ \\
\hline $\begin{array}{c}\text { Dalal \& Broacha } \\
\text { Portfolio Managers }\end{array}$ & Multi Cap & Dalal \& Broacha Long Term Growth & $21.16 \%$ & $5.29 \%$ & $9.56 \%$ & $7.47 \%$ \\
\hline Nippon India & Large Cap & Nippon India Absolute Freedom & $10.00 \%$ & $5.40 \%$ & $8.30 \%$ & $7.00 \%$ \\
\hline Accuracap & Small Cap & Accuracap - Picopower & $10.20^{\prime} \%$ & $13.10 \%$ & $2.60 \%$ & $6.80 \%$ \\
\hline
\end{tabular}

Source: PMS Bazaar report "PMS \& AIF" 2020

\section{Analysis and Interpretation}

Table 1 depicts that majority of PMS funds failed to beat the benchmark in the short as well as the medium term. In the one-year time frame, nine out of the seventeen PMS funds failed to outperform the underlying benchmark. Further, only $29.41 \%$ and $58.82 \%$ of the PMS funds have managed to outperform the underlying benchmark indices in three- year and five-year period, respectively. But it is important to note that if the performance is evaluated over ten years, then all the PMS funds have beaten the benchmark.

Further, from Table 2 it can be observed that the best returns over five years have been given by Ambit capital of $12.00 \%$. It is pertinent to note that only three more PMS have given a pre-fee return of over $10 \%$, namely Narloia, ASK Investment Managers, and Alchemy Capital Management. The remaining PMS funds have generated pre-fees returns below $10 \%$, which is extremely poor considering the risk as compared to safe havens like PPF or Post office schemes providing risk-free returns of around $8 \%$. Further, if you reduce the pre-fees return by a minimum of $2-3 \%$ due to management fees and performance fees, then the post-fees return has mostly been less than even safe government debt instruments.

As seen in Table 3, the worst returns over five years of $1.63 \%$ have been given by PGIM India PMS fund, followed by Concept Invest well Pvt Ltd of $2.65 \%$, as seen in Table 3. The other funds have also given returns lower than safe government deposits like the post office, PPF, etc. 
Furthermore, once the fees are deducted from the post fees, returns will be even less indicating that investors in these funds have got minimal returns on their investments in a period where the stock markets did pretty decently.

\subsection{PMS Funds Fees Structure}

The fixed fees charged by the PMS funds are in line with active mutual funds, where the total expense ratio is capped at $2.5 \%$ [3] as seen in Table 4. But the variable fees charged by the majority of the PMS funds are based on a very conservative hurdle rate of $10 \%$ and less. The regulators should look at making suitable legislation to ensure a much higher minimum hurdle rate for PMS funds, which is commensurate with the risks involved in equity investments (equity risk premium) and the high variable fees being charged by these PMS funds.

Table 3. Worst performing strategy-wise PMS funds in the last 5 years(all performance as on $29^{\text {th }}$ February 2020 . Returns are in $\%$ CAGR and reported pre fees)

\begin{tabular}{|c|c|c|c|c|c|c|}
\hline PMS Name & Category & Strategy & 1 Year & 2 Year & 3 Year & 5 Year \\
\hline PGIM lndia & Multi Cap & PGIM India - Core Equity Portfolio & $1.51 \%$ & $1.55 \%$ & $-3.73 \%$ & $1.63 \%$ \\
\hline $\begin{array}{c}\text { Concept Investwell } \\
\text { Pvt Ltd }\end{array}$ & Mid Cap & Concept Investwell - Marvell & $5.54 \%$ & $-26.07 \%$ & $-2.97 \%$ & $2.65 \%$ \\
\hline Centrum PMS & Multi Cap & Centrum -Weal Th Creator & $9.80 \%$ & $2.5 \%$ & $4.30 \%$ & $6.10 \%$ \\
\hline $\begin{array}{c}\text { Concept Investwell } \\
\text { Pvt Ltd }\end{array}$ & Large Cap & Concept Investwell - Legend & $17.66 \%$ & $9.18 \%$ & $7.54 \%$ & $6.27 \%$ \\
\hline Accuracap & Small Cap & Accuracap - Picopower & $10.20 \%$ & $-13.10 \%$ & $2.60 \%$ & $6.80 \%$ \\
\hline Nippon India & Large Cap & Nippon India - Absolute Freedom & $10.00 \%$ & $5.40 \%$ & $8.30 \%$ & $7.00 \%$ \\
\hline $\begin{array}{c}\text { Dalal \& Broacha } \\
\text { Portfolio Managers }\end{array}$ & Multi Cap & Dalal \& Broacha - Long Term Growth & $21.16 \%$ & $5.29 \%$ & $9.56 \%$ & $7.47 \%$ \\
\hline
\end{tabular}

Source: PMS Bazaar report "PMS \& AIF" 2020

Table 4. Fees charged by various PMS funds

\begin{tabular}{|c|c|c|c|}
\hline PMS Name & Fixed Fees & Variable Fees (Profit Sharing) & Hurdle Rate \\
\hline ASK- IEP & $1.5 \%$ & $20 \%$ Of Performance Over $10 \%$ On Compounded Hurdle & $10 \%$ \\
\hline Narnolia - India 3T & $1.5 \%$ & $\begin{array}{c}\text { Profit }>10 \%<15 \%-15 \% \text { Profit Sharing/ Profit Above }>15 \%-20 \% \text { Profit } \\
\text { Sharing }\end{array}$ & $10 \%$ \\
\hline $\begin{array}{l}\text { Ambit Capital - Good \& } \\
\text { Clean India Fund }\end{array}$ & $0 \%$ & $20 \%$ Profit Sharing Above $8 \%$ Hurdle & $8 \%$ \\
\hline Alchemy - High Growth & $1.5 \%$ & $\begin{array}{c}5 \% \text { Above The } 10 \% \text { Hurdle, Charged Annually at The End of Every } \\
\text { Year Starting }\end{array}$ & $10 \%$ \\
\hline $\begin{array}{l}\text { PGIM India - Core Equity } \\
\text { Portfolio }\end{array}$ & $2.5 \%$ & Nil & NA \\
\hline $\begin{array}{l}\text { Concept Investwell - } \\
\text { Marvell }\end{array}$ & $1.25 \%$ & $10 \%$ Profit Sharing Above $8 \%$ Hurdle & $8 \%$ \\
\hline Centrum - Wealth Creator & $2 \%$ & Nil & NA \\
\hline Accuracap - Picopower & $1.5 \%$ & $\begin{array}{l}\text { 20\% Of Excess Returns Generated Over 12\% Hurdle at The End of } \\
\text { Every FY (Subject to Investment Period of Minimum } 6 \text { Months) On A } \\
\text { High Watermark Basis }\end{array}$ & $12 \%$ \\
\hline
\end{tabular}

Source: "PMS Guide" March 2020 
Hence, we can interpret that PMS funds in India collectively have not created any significant abnormal returns to justify the extremely high management and performance fees being charged from their investors. These PMS funds also are likely to face substantial tailwinds due to the COVID-19 pandemic, which has resulted in a sharp $30 \%$ fall in the Indian stock markets in March 2020. The first casualty of this stock market plunge is the closure of PMS fund of IndiaNivesh with an AUM of INR 60 crores [4].

\section{Conclusions and Implications}

This study describes the performance of Portfolio Management Services in India. The findings indicate that a large number of PMS funds have given poor returns net of fees in short- and medium-term time frame. High net worth individuals are advised to invest in PMS funds only if they have an investment horizon of at least ten years to earn excess returns compared to benchmark indices. HNIs are better off investing in passive mutual index funds or Exchange Traded Funds (ETF) for short- or medium-term equity exposure as these funds have a meager expense ratio and track the performance of the benchmark indices [27].

The study also has policy implications in the Indian context. The Indian market regulators must investigate the extremely low level of hurdle rates set by most of PMS funds to garner variable fees. The regulator should set a higher hurdle rate, which must be achieved to get incentive fees. Further, SEBI must devise disclosure norms to improve the reporting quality of PMS funds performance for researchers to deploy suitable econometric techniques for historical performance just like mutual funds.

There are several limitations of the study. Performance of all PMS funds has not been covered in this study due to limited data availability. Secondly, due to limited data availability on SEBI website, the analysis is based on the data obtained from third party aggregator which has listed PMS funds' performance as compared to benchmark. Third, the results of study are only applicable in an Indian context and not universally valid at a world level. Future research can focus on extending the analysis at more granular level and also deploy econometric techniques when adequate data is available for academicians.

\section{Acknowledgements}

The authors would like to thank the three anonymous reviewers for their careful evaluation of our manuscript and for valuable feedback and suggestions. Incorporating the suggested changes has helped us a lot to improve the quality of the paper.

\section{REFERENCES}

[1] Agarwal, V., Green, T. C., \& Ren, H. (2018). Alpha or beta in the eye of the beholder: What drives hedge fund flows? Journal of Financial Economics, Elsevier, Vol. 127(3), 417-434. doi:10.1016/j.jfineco.2018.01.006

[2] Agarwal, V. and Naik, N.Y. (2000), "Multi-period performance persistence analysis of hedge funds", Journal of Financial and Quantitative Analysis, Cambridge University Press, Vol. 35 No. 3, pp. 327-342. doi:10.2307/2676207

[3] AMFI India (2020): "What Is Expense Ratio?", https://www.amfiindia.com/investor-corner/knowledge-cen ter/Expense-Ratio.html (accessed on 2 April 2020)

[4] Bloomberg Quint (2020): “IndiaNivesh Closes PMS Business", 29 March, 2020 https://www.bloombergquint.com/markets/indianivesh-clo ses-pms-business. (accessed on 13 April)

[5] Bogle, J.C. (2016), "The index mutual fund: 40 years of growth, change, and challenge", Financial Analysts Journal, Taylor \& Francis, Vol. 72 No. 1, pp. 9-13.

[6] Capocci, D. and Hübner, G. (2004), "Analysis of hedge fund performance", Journal of Empirical Finance, Elsevier, Vol. 11 No. 1 , pp. 55-89.

[7] Carhart, M.M. (1997), "On persistence in mutual fund performance", The Journal of Finance, Wiley Online Library, Vol. 52 No. 1, pp. 57-82.

[8] Chakraborty, M., Jain, P.K. and Kallianpur, V. (2008), "Mutual Fund Performance: An Evaluation of Select Growth Funds in India.", South Asian Journal of Management, Vol. 15 No. 4.

[9] Cornell, B., Hsu, J., Kiefer, P. and Wool, P. (2020), "Assessing Mutual Fund Performance in China", The Journal of Portfolio Management, Institutional Investor Journals Umbrella, Vol. 46 No. 5, pp. 118-127.

[10] Crane, A.D. and Crotty, K. (2018), "Passive versus active fund performance: do index funds have skill?", Journal of Financial and Quantitative Analysis, Cambridge University Press, Vol. 53 No. 1, pp. 33-64.

[11] Cremers, K.M., Fulkerson, J.A. and Riley, T.B. (2019), "Challenging the conventional wisdom on active management: A review of the past 20 years of academic literature on actively managed mutual funds", Financial Analysts Journal, Taylor \& Francis, Vol. 75 No. 4, pp. 835.

[12] Dichev, I.D. and Yu, G. (2011), "Higher risk, lower returns: What hedge fund investors really earn", Journal of Financial Economics, Elsevier, Vol. 100 No. 2, pp. 248263.

[13] Djerroud, B., Saunders, D., Seco, L. and Shakourifar, M. (2016), "Pricing shared-loss hedge fund fee structures", Innovations in Derivatives Markets, Springer, Cham, pp. 369-383. 
[14] Dyck, A., Lins, K.V. and Pomorski, L. (2013), "Does active management pay? New international evidence", The Review of Asset Pricing Studies, Oxford University Press, Vol. 3 No. 2, pp. 200-228.

[15] Fama, E.F. and French, K.R. (2010), "Luck versus skill in the cross-section of mutual fund returns", The Journal of Finance, Wiley Online Library, Vol. 65 No. 5, pp. 19151947.

[16] Fasano, A. and Boido, C. (2017), "Concentration and behavioral biases in the active management of Bric funds", Ekonomika (Economics), Sciendo, Vol. 96 No. 1, pp. 5873 .

[17] Fichtner, J., Heemskerk, E.M. and Garcia-Bernardo, J. (2017), "Hidden power of the Big Three? Passive index funds, re-concentration of corporate ownership, and new financial risk", Business and Politics, Cambridge University Press, Vol. 19 No. 2, pp. 298-326.

[18] Fraś, A. (2018), "Expensive and Cheap Funds-Polish Stock Mutual Fund Fees in 2017", Financial Sciences. Nauki o Finansach, Sciendo, Vol. 23 No. 4, pp. 38-49.

[19] Goetzmann, W.N., Ingersoll Jr, J.E. and Ross, S.A. (2003), "High-water marks and hedge fund management contracts", The Journal of Finance, Wiley Online Library, Vol. 58 No. 4, pp. 1685-1718.

[20] Guercio, D.D. and Reuter, J. (2014), "Mutual fund performance and the incentive to generate alpha", The Journal of Finance, Wiley Online Library, Vol. 69 No. 4, pp. 1673-1704.

[21] He, X.D. and Kou, S. (2018), "Profit sharing in hedge funds", Mathematical Finance, Wiley Online Library, Vol. 28 No. 1 , pp. 50-81.

[22] Jensen, M.C. (1968), "The performance of mutual funds in the period 1945-1964", The Journal of Finance, Wiley Online Library, Vol. 23 No. 2, pp. 389-416.

[23] Kremnitzer, K. (2012), "Comparing active and passive fund management in emerging markets", University of California, Berkeley, Economics Department. Senior Honors Thesis.

[24] Marios, A., Kalliopi, D., Evangelia, P. and Paraskevi, P. (2020), "Performance Evaluation of Global High-rated ETFs During the Taper Tantrum", Journal of Central Banking Theory and Practice, Sciendo, Vol. 9 No. 1, pp. $23-44$
[25] Mehmet Nar (2021). The Relationship between Credit Default Swaps and Net Portfolio Investments: The Case of Turkey. Universal Journal of Accounting and Finance, 9(2), 252 - 261. DOI: 10.13189/ujaf.2021.090215.

[26] Naveenan, R. V. (2019). Risk and return analysis of portfolio management services of Reliance Nippon Asset Management limited (RNAM). Global Journal of Management and Business, 6(1), 108-117

[27] NSEINDIA (2020): " Index Funds" , https://www1.nseindia.com/products/content/equities/indic es/index_funds.htm . (accessed on 5 April 2020)

[28] Pástor, L., Stambaugh, R.F. and Taylor, L.A. (2015), "Scale and skill in active management", Journal of Financial Economics, Elsevier, Vol. 116 No. 1, pp. 23-45.

[29] PMS Bazaar (2020): "PMS \& AIF" https://resources.pmsbazaar.com/special-edition/PMS_AIF _Special_Edition.pdf?. (accessed on 12 April 2020)

[30] PMS Bazaar (2020): " PMS Guide" , https://resources.pmsbazaar.com/pms-guide/2020/PMSBaz aarPMSGuideMarch2020.pdf?. (accessed on 12 April 2020)

[31] Rastogi, S. (2015). Identification of Factors for Investments in Mutual Funds through Banks. Asia-Pacific Journal of Management Research and Innovation, 11(2), 128-133.

[32] Roy, B. and Deb, S.S. (2004), "Conditional alpha and performance persistence for Indian mutual funds: empirical evidence", ICFAI Journal of Applied Finance, pp. 30-48.

[33] Schmidt, C. and Fahlenbrach, R. (2017), "Do exogenous changes in passive institutional ownership affect corporate governance and firm value?", Journal of Financial Economics, Elsevier, Vol. 124 No. 2, pp. 285-306.

[34] Tripathy, N. (2017), "Efficiency of mutual funds and performance measurement in India: an empirical investigation", International Journal of Business Excellence, Inderscience Publishers (IEL), Vol. 13 No. 2, pp. 217-237.

[35] Tokic, Damir. "The passive investment bubble." (2020): 7-11.

[36] Tripathy, N.P. (2006), "Market Timing Abilities and Mutual Fund Performance: An Empirical Investigation into Equity Linked Saving Schemes", Vilakshan, XIMB Journal of Management, Vol. 3 No. 2, pp. 127-138. 